The Asami Library 



\title{
The Asami Library
}

A DESCRIPTIVE CATALOGUE

\author{
by \\ CHAOYING FANG \\ edited by \\ Elizabeth $\mathrm{Huff}$
}

Berkeley and Los Angeles 1969

UNIVERSITY OF CALIFORNIA PRESS 
University of California Press

Berkeley and Los Angeles, California

University of California Press, Ltd.

London, England

Copyright (1) 1969, by

The Regents of the University of California

Library of Congress Catalog Card Number: 69-16505

Printed in the United States of America 